\title{
Temporal expression and cellular localization of a gastrin-releasing peptide-related gene in ovine uterus during the oestrous cycle and pregnancy
}

\author{
J C Whitley, A Shulkes, L A Salamonsen ${ }^{1}$, D Vogiagis ${ }^{1}$, \\ M Familari $^{2}$ and A S Giraud ${ }^{2}$ \\ University of Melbourne Department of Surgery, Austin and Repatriation Medical Centre, Austin Campus, Melbourne, Victoria, Australia, ${ }^{1}$ Prince Henry's \\ Institute of Medical Research, Monash Medical Centre, Clayton, Victoria, Australia and ${ }^{2}$ University of Melbourne Department of Medicine, \\ Western Hospital, Footscray, Victoria, Australia \\ (Requests for offprints should be addressed to J Whitley, University of Melbourne Department of Surgery, Austin and Repatriation Medical Centre, \\ Austin Campus, Melbourne, Victoria 3084, Australia)
}

\begin{abstract}
Synthesis of both mRNA and peptide for gastrin-releasing peptide (GRP) has been demonstrated in the pregnant endometrium of sheep and women. However, it is not known whether GRP is synthesized in the sheep uterus during the oestrous cycle. Furthermore the cellular site of GRP mRNA synthesis in the uterus has not been determined. Therefore we examined the synthesis of GRP and determined the cellular location of GRP peptide and mRNA in sheep uterus taken at different times during the oestrous cycle (duration 17 days) and pregnancy (duration 145 days). Northern blot analysis of RNA isolated from ovine endometrium revealed low or no GRP mRNA at days 4, 10, 12 and 14 of the oestrous cycle and a 24-fold rise in GRP mRNA (normalized to glyceraldehyde-3phosphate dehydrogenase (GAPDH) mRNA) between days 14 and 16. A similar pattern was observed during early pregnancy, with a 12-fold rise in GRP mRNA:GAPDH mRNA between days 17 and 20 of pregnancy. Levels of GRP peptide were determined by RIA and found to be low in endometrium isolated at days 4, 10, 12 and 14 of the oestrous cycle $(1 \cdot 0-1.6 \mathrm{pmol} / \mathrm{g})$ and 4 to 5 -fold higher at day 16. In situ hybridization localized GRP synthesis to the epithelial cells of the uterine glands at day 16 of the oestrous cycle and at days 17, 20, 40 and 50 of pregnancy. At day 140 of pregnancy diffuse hybrid-
\end{abstract}

ization to cells of the myometrium was also observed. Immunohistochemistry localized GRP peptide to the apical cytoplasm of uterine glandular epithelial cells at day 16 of the oestrous cycle. For samples obtained at day 20 of pregnancy, the area surrounding the glands also showed moderately strong staining. Further staining in the glandular lumen and the stromal tissue surrounding the glands was apparent at day 140 of pregnancy. No GRP immunoreactivity could be detected in the peripheral plasma during the oestrous cycle or the first 20 days of pregnancy. Sizing chromatography of GRP immunoreactivity extracted from endometrial tissue taken at day 10 of the oestrous cycle revealed two peaks that co-eluted with GRP(1-27) and GRP(18-27). However, during luteolysis and oestrus the major peak of GRP immunoreactivity extracted from endometrial tissue was larger than GRP(127 ) and similar to that seen previously in the gravid ovine endometrium. These studies demonstrate that a peptide similar to, but larger than, GRP is a major product of the glandular epithelium of the ovine uterus during the luteal regression phase of the oestrous cycle and post-blastocyst implantation in pregnancy and provide further evidence that GRP-related peptides have important regulatory roles in uterine function.

Journal of Endocrinology (1998) 157, 139-148

\section{Introduction}

Gastrin-releasing peptide (GRP) is a mammalian homologue of amphibian bombesin and was named for its ability to stimulate the release of gastrin, hence the traditional view of it as a gastrointestinal regulatory peptide (see Bunnett 1994 for review). However, it has subsequently been shown that GRP is widely expressed in the mammalian brain, lung, pancreas and anterior pituitary
(Bunnett 1994) and more recently in the pregnant uterus of humans and sheep (Fraser et al. 1992, 1994, Giraud et al. 1993, 1994, Shulkes et al. 1996, Whitley et al. 1996, Xiao et al. 1996a).

Our previous studies have detected GRP immunoreactivity in the uteroplacental tissues (endometrium, myometrium, amnion, chorioallantois) and fluids (foetal lung fluid and urine, amniotic and allantoic fluids) of the pregnant ewe, as well as in the foetal and maternal 
circulations throughout the last third of gestation (Giraud et al. 1993). Immunohistochemistry revealed GRP-like immunoreactivity in glandular epithelial cells, but not neuroendocrine cells of the pregnant endometrium. These were surprising findings considering the general role of GRP as a neurotransmitter, and suggested a hormonal role for the endometrial GRP-like peptide in foetal development. Northern blot analysis of GRP mRNA indicated that the sites of synthesis were the near-term pregnant endometrium and myometrium but not the amnion or chorioallantois (Shulkes et al. 1996). GRP mRNA was approximately 150-fold lower in the non-pregnant endometrium and not detected in the non-pregnant myometrium (Whitley et al. 1994). We have noticed a similar pattern of expression in the human uterus (Whitley et al. 1996).

The high abundance in the pregnant endometrium coupled with the known mitogenic effects of GRP implies an important growth-promoting role for a GRP-related peptide in the uterus. This peptide also may be involved in implantation of the blastocyst, as we have observed a 10-fold increase in GRP mRNA in the endometrium just before implantation at day 16/17 of pregnancy (Giraud et al. 1994). Preliminary characterization of the GRPrelated peptide indicated that it is larger than the known forms of GRP including GRP(1-27), suggesting that it is a novel uterus-specific form of GRP (Giraud et al. 1996, Xiao et al. 1996b).

In sheep, cattle and pigs, the majority of protein production by uterine endometrium and transport of serum-derived proteins into the uterine lumen occurs during the luteal phase of the oestrous cycle, in pregnancy, or in response to exogenous progesterone. In the pregnant ewe, the embryo enters the uterus about 4 days after ovulation (Rowson \& Moor 1966). After 8 days, the majority of embryos will have reached the blastocyst stage (characterized by a central cavity and presence of an embryonic disc) with a $1 \mathrm{~mm}$ diameter. After the 12th day, a period of rapid growth commences to form an elongated sac $12-33 \mathrm{~mm}$ in length. This rapid growth continues and by day 14-15 after fertilization the blastocyst is $70-100 \mathrm{~mm}$ in length. The first signs of attachment can be detected around day 16. Conceptus growth in the ewe is regulated in part by the maternal environment, possibly via paracrine secretion of endometrial factors (Lawson et al. 1983). These may be secreted into the uterine lumen and act directly on the conceptus or indirectly by controlling the release of secretory products from the uterine glands. Much is still unknown about the many factors released by the ewe endometrium during early pregnancy or about the regulation and interactions of these necessary factors for conceptus and uterine growth. Our previous studies have shown that a GRP-like peptide is expressed in early pregnancy (Giraud et al. 1994). However, it is not known whether GRP is expressed by the non-pregnant uterus, and if it is, whether the level of expression correlates with the stage of the oestrous cycle. The cellular localization of the peptide in early pregnancy and during the cycle is also not known. The objective of the present study was to determine the temporal variation of uterine GRP during the ovine oestrous cycle and compare this with early pregnancy. Northern blot analysis and RIA were used to determine the synthesis, storage and secretion of uterine GRP, and in situ hybridization and immunohistochemistry were used to ascertain the cellular sites of synthesis and storage. The nature of the uterine GRP synthesized during the oestrous cycle was characterized by sizing chromatography.

\section{Materials and Methods}

\section{Animals}

Sheep were prepared by one of two methods. In protocol 1 , the oestrous cycles of parous Corriedale ewes were synchronized by treatment for 12 days with intravaginal inserts containing progesterone (CIDR-G; EAZI-breed, Riverina Breeders Pty Ltd, Albury, Vic., Australia) and an injection of the prostaglandin analogue cloprostenol (125 $\mu \mathrm{g}$ Estrumate; Pitman-Moore, North Ryde, NSW, Australia) 1 day before withdrawal of the progesterone insert. Ewes were mated at the subsequent oestrus with either vasectomized or intact rams bearing a marking harness as described previously (Salamonsen et al. 1986). On the evening before surgery, animals were penned, and food and water were withheld. On days 4, 10, 12, 14 and 16 after oestrus (day 0) and on days 4, 7, 8, 9, 10, 12, 14, $15,16,17$ and 20 of pregnancy, the animals (three to six in each group) were anaesthetized, and hysterectomy performed as described previously (Salamonsen et al. 1986). Pregnancy was confirmed by the presence of an embryo in the lumen, either removed by flushing with $20 \mathrm{ml}$ saline (days 4-16) or by visualization after hysterectomy (days 17 and 20). Endometrium was collected and either frozen at $-70{ }^{\circ} \mathrm{C}$ before extraction of RNA and peptide or frozen in embedding compound (OCT; Miles Inc, Elkhart, IN, USA) for analysis by in situ hybridization and immunohistochemistry.

Blood samples were collected from a separate group of control ewes mated with either vasectomized or intact rams for another study (Vogiagis et al. 1997). Frozen plasma samples $\left(-70{ }^{\circ} \mathrm{C}\right.$ for 10 months) from days 4,10 , $12,14(n=4)$ and $16(n=3)$ of the oestrous cycle and early pregnancy were thawed, $1 \mathrm{ml}$ was removed and EDTA was added to $1 \mathrm{mM}$ to inhibit proteases during the RIA. The samples were stored again at $-70{ }^{\circ} \mathrm{C}$ until RIA 4 days later.

In protocol 2, mature Corriedale ewes with normal oestrous cycles were used during the breeding season and mated with a vasectomized ram. At 10-12 days after mating, luteolysis was induced by injection (i.m.) with cloprostenol (Estrumate). Previous data have shown that 
ewes treated in this way normally have a preovulatory luteinizing hormone surge within 40-70 h of a cloprostenol injection (Tsonis et al. 1984). Endometrial tissue was taken from sheep culled at day 8 (before cloprostenol injection), $30 \mathrm{~h}$ after cloprostenol injection (considered to be equivalent to the luteal regression phase) and $48 \mathrm{~h}$ after cloprostenol injection (when ewes are sexually receptive to the ram and therefore in oestrus).

Tissues taken from sheep treated as described in protocol 2 were used for characterization of uterine GRP by sizing chromatography. Tissues taken from sheep treated as described in protocol 1 were used for all other studies. All animal experimentation was approved by the animal ethics committees at the Animal Research Institute, Werribee and Monash Medical Centre, Clayton, Victoria.

\section{Isolation of RNA and Northern blot analysis for GRP $m R N A$ and glyceraldehyde-3-phosphate dehydrogenase (GAPDH) $m R N A$}

Total RNA was isolated as reported previously (Whitley et al. 1996) from the endometrial tissues taken on days 4 , $10,12,14$ and 16 of the oestrous cycle and on days 4,7 , $8,9,10,12,14,15,16,17$ and 20 of pregnancy. A $20 \mu \mathrm{g}$ portion of each was separated by agarose gel electrophoresis before transfer to nylon membranes (Hybond $\mathrm{N}$; Amersham, Melbourne, Vic., Australia). Northern blot analysis for GAPDH mRNA and GRP mRNA using radiolabelled ovine cDNAs as probes was performed essentially as described previously (Giraud et al. 1994). GRP mRNA was detected after autoradiography for approximately $24 \mathrm{~h}$ using two intensifying screens. GRP mRNA was quantified by laser densitometry (LKB Ultroscan XL Enhanced Laser Densitometer, LKB/ AMRAD, Kew, Vic, Australia) and normalized to the amount of GAPDH mRNA.

\section{In situ hybridization}

Riboprobe preparation ${ }^{33} \mathrm{P}$-labelled antisense and sense cRNA probes were prepared by in vitro transcription from cloned ovine GRP cDNA. Approximately $1 \mu \mathrm{g}$ linearized DNA was included in a reaction mixture consisting of $40 \mathrm{mM}$ Tris- $\mathrm{HCl}$ ( $\mathrm{pH} 7 \cdot 9$ ), $6 \mathrm{mM} \mathrm{MgCl}_{2}, 2 \mathrm{mM}$ spermidine, $10 \mathrm{mM} \mathrm{NaCl}, 10 \mathrm{mM}$ dithiothreitol, $0.5 \mathrm{mM}$ GTP, ATP and CTP, 40 U RNasin (Promega, Madison, WI, USA), $2 \cdot 8 \mu \mathrm{M}\left[{ }^{33} \mathrm{P}\right] \mathrm{UTP}(1000-3000 \mathrm{Ci} / \mathrm{mmol})$, $7 \cdot 2 \mu \mathrm{M}$ unlabelled UTP and $10 \mathrm{U}$ T3 or T7 RNA polymerase (Promega). After incubation at $37^{\circ} \mathrm{C}$ for $1 \mathrm{~h}$, $0.5 \mu \mathrm{g}$ RNase-free DNase I (Boehringer-Mannheim, Sydney, NSW, Australia) was added and incubation continued for $15 \mathrm{~min}$ at $37^{\circ} \mathrm{C}$. The reaction volume was made up to $50 \mu \mathrm{l}$, and radiolabelled probe was purified using a ProbeQuant G-50 Micro column (Pharmacia-Amrad, Kew, Vic, Australia) according to the manufacturer's instructions.
Hybridization conditions Sections $(5 \mu \mathrm{m})$ of uterus frozen in embedding compound (OCT) were thawed on to silane coated glass slides and baked at $50{ }^{\circ} \mathrm{C}$ for $2 \mathrm{~h}$. Mounted sections were rehydrated by immersion in $100 \%$ ethanol $(2 \times 2 \mathrm{~min}), 95 \%$ ethanol $(1 \times 2 \mathrm{~min}), 70 \%$ ethanol $(1 \times 2 \mathrm{~min})$ and then water (brief rinse). They were then immersed in proteinase $\mathrm{K}$ buffer $(50 \mathrm{mM}$ Tris- $\mathrm{HCl}$, $\mathrm{pH} 7.5$ ) (5 min), fresh proteinase $\mathrm{K}$ buffer containing $10 \mu \mathrm{g} / \mathrm{ml}$ proteinase $\mathrm{K}\left(10 \mathrm{~min} ; 37^{\circ} \mathrm{C}\right)$, PBS containing $2 \mathrm{mg} / \mathrm{ml}$ glycine $(2 \mathrm{~min})$, PBS $(2 \times 1 \mathrm{~min}), 4 \%$ paraformaldehyde $(10 \mathrm{~min})$, PBS $(2 \times 1 \mathrm{~min})$, acetylation buffer $(0 \cdot 1 \mathrm{M}$ triethanolamine, $0 \cdot 25 \%$ acetic anhydride) (10 min), PBS $(2 \times 1 \mathrm{~min})$ and finally dehydrated in 70 , 95 and 100\% ethanol $(20 \mathrm{~s}$ each). The sections were then hybridized overnight at $50{ }^{\circ} \mathrm{C}$ in the presence of $50 \mu \mathrm{l}$ hybridization buffer $(50 \%$ deionized formamide, $5 \times \mathrm{SSC}$ $(1 \times \mathrm{SSC}=0.015 \mathrm{M} \mathrm{NaCl}$ and $0.015 \mathrm{M}$ sodium citrate, $\mathrm{pH} 7 \cdot 0), 0 \cdot 1 \mathrm{M} \mathrm{NaH}_{2} \mathrm{PO}_{4}(\mathrm{pH} 7 \cdot 0), 10 \mathrm{mM}$ dithiothreitol, $100 \mu \mathrm{g} / \mathrm{ml} \mathrm{tRNA}, 100 \mu \mathrm{g} / \mathrm{ml}$ single-stranded sheared salmon sperm DNA, $1 \times$ Denhardt's solution) containing 50000 d.p.m. sense or antisense probe. After hybridization, the slides were rinsed in $50 \%$ formamide $/ 5 \times \mathrm{SSC}$ $\left(60 \mathrm{~min} ; 50{ }^{\circ} \mathrm{C}\right)$, followed by RNase A digestion buffer $(0 \cdot 3 \mathrm{M} \mathrm{NaCl}, 10 \mathrm{mM}$ Tris-HCl, $\mathrm{pH} 8 \cdot 0,5 \mathrm{mM}$ EDTA) $\left(3 \times 5 \mathrm{~min} ; 37^{\circ} \mathrm{C}\right)$ and then fresh RNase A digestion buffer containing $20 \mu \mathrm{g} / \mathrm{ml}$ RNase A (Sigma) for $30 \mathrm{~min}$ at $37^{\circ} \mathrm{C}$. The slides were then washed under conditions of increasing stringency using $2 \times$ SSC and finally $0.5 \times$ SSC $\left(30 \mathrm{~min}\right.$ each; $65^{\circ} \mathrm{C}$ ) and then dehydrated $(70,95$ and $100 \%$ ethanol, $2 \times 1 \mathrm{~min}$ each). The slides were exposed to XAR-5 film (Kodak, Coburg, Vic., Australia) for 6 days. After development of the film, the slides were coated with NTB-2 photographic emulsion according to the manufacturer's instructions (Kodak), stored for 7 days and then developed, stained and photographed.

\section{$R I A$}

GRP immunoreactivity was measured by a previously described RIA (Giraud et al. 1994) using polyclonal antiserum R40 raised against $\left[\mathrm{Lys}^{3}\right]$-bombesin (kindly donated by Professor B Jarrott, Department of Pharmacology, Monash University, Melbourne, Vic, Australia). The RIA uses ${ }^{125} \mathrm{I}-\left[\mathrm{Tyr}^{4}\right]$-bombesin as tracer. The assay diluent was $0.7 \mathrm{ml} 25 \mathrm{mM}$ phosphate buffer containing $0 \cdot 1 \% \mathrm{BSA}$ and $2 \mu \mathrm{M} \mathrm{NaN}$, to which were added $100 \mu \mathrm{l}$ label (5000 c.p.m.), $100 \mu \mathrm{l}$ antibody R40 (1:100 000 final concentration) and $100 \mu \mathrm{l}$ sample or standard. Tubes were incubated for $48 \mathrm{~h}$ at $4{ }^{\circ} \mathrm{C}$, and bound counts were separated from free by the addition of $300 \mu \mathrm{l}$ of a cocktail consisting of equal volumes of goat anti-serum IgG (plasma diluted 1:60 in assay buffer), non-immune rabbit plasma (1:600) and polyethylene glycol (10\%), followed by centrifugation $(2000 \boldsymbol{g} ; 30 \mathrm{~min})$. Non-specific binding was $1.5 \pm 0.09 \%(n=47)$. The RIA standard was bombesin $(3 \cdot 9-1000 \mathrm{fmol} / \mathrm{ml}) ; 50 \%$ inhibition of label binding 
occurred at $125 \pm 7 \mathrm{fmol} / \mathrm{ml}(n=48)$. Inter- and intraassay coefficients of variation were 14 and $4 \%$ respectively. The antiserum is directed to the amidated $\mathrm{C}$-terminus and cross-reacts $100 \%$ with bombesin, $\left[\mathrm{Tyr}^{4}\right]$-bombesin, GRP(18-27) and GRP(1-27) and less than $0 \cdot 1 \%$ with neuromedin $\mathrm{B}$ and substance $\mathrm{P}$. The detection limit per assay tube was $4 \mathrm{fmol} / \mathrm{ml}$.

\section{Immunohistochemistry}

Sections $(10 \mu \mathrm{m})$ of whole uterus, fixed for $4-6 \mathrm{~h}$ in fresh $4 \%$ paraformaldehyde and embedded in paraffin were stained using an indirect peroxidase technique and an avidin-biotin kit (Vectalabs, Burlingame, CA, USA). The primary antiserum $\mathrm{AB}$ 11-6 was raised in a rabbit immunized with $\left[\mathrm{Lys}^{4}\right]$-bombesin coupled to key-hole limpet haemocyanin conjugate and was used at 1:500-1:1000 dilution. Method specificity was tested by incubation with normal rabbit serum, and antiserum specificity by incubation with bombesin or GRP(18-27).

\section{Chromatography}

Endometrial tissue samples were taken from sheep $(n=3)$ that had been prepared as described in protocol 2. Endometrium $(11 \mathrm{~g})$ was boiled in 10 volumes $3 \%$ glacial acetic acid at $95{ }^{\circ} \mathrm{C}$ for $5 \mathrm{~min}$, centrifuged and the supernatant subjected to solid phase extraction on $\mathrm{C}_{18}$ Sep-Pak (Waters Australia Pty Ltd, Rydalmere, NSW, Australia). The subsequent eluate was dried, reconstituted in 3\% glacial acetic acid, and chromatographed on a column $(1.5 \times 90 \mathrm{~cm})$ of Sephadex G-50 with $3 \%$ glacial acetic acid as the eluent. Fractions $(100 \times 1.4 \mathrm{ml})$ were collected, lyophilized, and assayed for GRP immunoreactivity by RIA. The column was calibrated with BSA (void volume), ovine GRP(1-27) and ovine GRP(18-27).

\section{Statistical analysis}

The data for GRP immunoreactivity in tissue samples were analysed by descriptive statistics, whereas the data for GRP mRNA synthesis (normalized to GAPDH mRNA) in endometrium isolated during the oestrous cycle or pregnancy were analysed by one-way ANOVA followed by the Tukey test for all pairwise multiple comparisons. Comparison between the oestrous cycle and pregnancy for the amount of GRP mRNA synthesis in endometrial tissue was made using two-way ANOVA followed by the Tukey test for pairwise multiple comparisons. These analyses were performed using SigmaStat statistical software (Jandel Scientific, San Rafael, CA, USA). P $<0 \cdot 05$ was accepted as significant. Data are presented as the mean \pm S.E.M.

\section{Results}

Northern blot analysis for GRP $m R N A$ during the oestrous cycle and early pregnancy

A $1 \mathrm{~kb}$ mRNA transcript was detected using ovine GRP cDNA as a probe. There was variable and low detection of GRP mRNA in endometrium isolated at days 4, 10, 12 and 14 of the oestrous cycle (Fig. 1a). Synthesis of GRP mRNA was normalized to the synthesis of GAPDH mRNA which was observed to decline slightly at day 16 of the oestrous cycle and moderately after day 14 of pregnancy; however, correction for GAPDH expression did not affect the overall trends in variation of GRP mRNA reported. The ratio of GRP mRNA to GAPDH mRNA was seen to increase markedly at day 16 of the oestrous cycle with a 24-fold rise compared with day 14 (Fig. 1c). For endometrium isolated during pregnancy (Fig. $1 b)$, there was low or no detection of GRP mRNA at days 4,7 and $8(n=4,3,3$ respectively, Fig. $1 c)$ and variable and low detection at days 9 and $10(n=6,5$ respectively, Fig. 1c). GRP mRNA was readily detected from day 12 of pregnancy (Fig. 1 b), and a marked increase $(7 \cdot 8$-fold) in GRP mRNA:GAPDH mRNA was observed between days 12 and 14 . This level was maintained on days 16 and 17 and was followed by a further increase at day 20 (12-fold). This pattern observed during pregnancy is similar to that reported previously in a different group of animals (Giraud et al. 1994). GRP mRNA:GAPDH mRNA on day 14 of the oestrous cycle was significantly lower than on day 14 of pregnancy (Fig. 1c). Conversely, GRP mRNA:GAPDH mRNA was significantly higher on day 16 of the oestrous cycle compared with day 16 of pregnancy (Fig. 1c).

\section{Cellular distribution of GRP $m R N A$}

Hybridization of the ovine GRP antisense riboprobe to the ovine uterus was compared for days 10 and 16 of the oestrous cycle and for days 9, 17, 20, 40, 50 and 140 of pregnancy (Fig. 2; data not shown for days 9, 17 and 50 of pregnancy). Under the conditions used, hybridization was not apparent at day 10 of the oestrous cycle (Fig. 2A) or day 9 of pregnancy (not shown). These observations are consistent with the Northern blot analysis (Fig. 1). At day 16 of the oestrous cycle (Fig. 2C) and day 17 of pregnancy (data not shown), specific hybridization was observed in the glandular epithelium only. No signal was detected in the luminal epithelium, intercaruncular stroma, caruncular stroma, blood vessels or myometrium. A gradation of hybridization was observed, with strongest expression of GRP mRNA in glands closest to the lumen (superficial glandular epithelium) and little or no expression at glands furthest from the lumen (deep glandular epithelium). For uterine tissue taken at days 20 and 40 of pregnancy (Figs $2 \mathrm{E}$ and $\mathrm{G})$ there was a further increase in hybridization to 
(a)
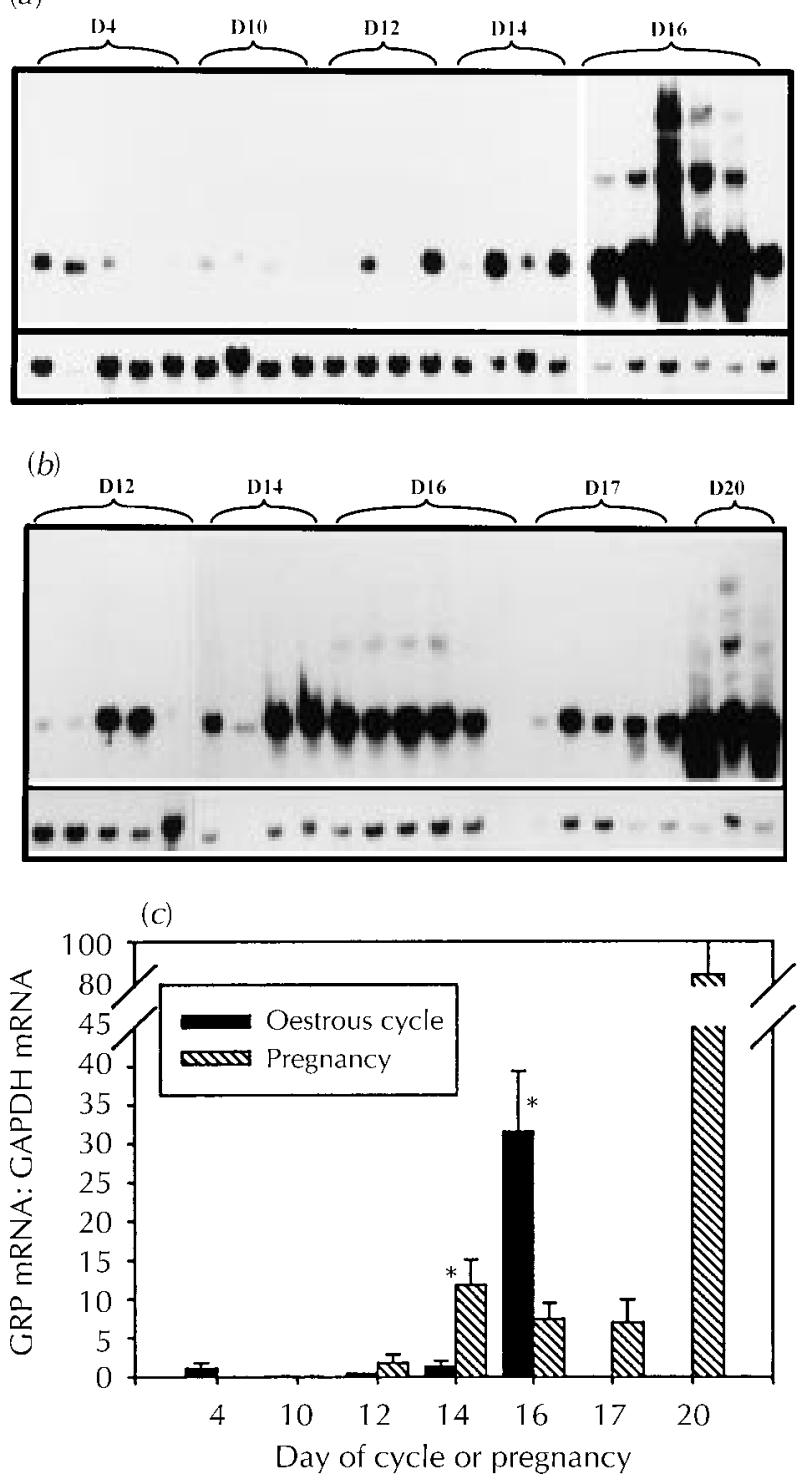

Figure 1 Expression of GRP mRNA (upper panels) and GAPDH mRNA (lower panels) in (a) endometrium obtained from sheep during the oestrous cycle (days 4, 10, 12, 14 and 16 as indicated) and in $(b)$ endometrium obtained from sheep during early pregnancy (days 12, 14, 16, 17 and 20 as indicated; days 4, 7, 8, 9 and 10 are not shown). A $20 \mu \mathrm{g}$ portion of total RNA from each sample was fractionated by denaturing gel electrophoresis, transferred to nylon membrane and subjected to hybridization using radiolabelled ovine GRP cDNA as probe. (c) Densitometric representation of GRP mRNA relative to GAPDH mRNA in endometrium isolated from sheep during the oestrous cycle and early pregnancy. Data are plotted as the mean \pm S.E.M. ${ }^{*} P<0 \cdot 05$ comparing oestrous cycle and pregnancy.

GRP antisense riboprobe by epithelial cells of glands closest to the lumen. Gradation of hybridization for superficial glands and deep glands continued to be observed. Intense hybridization of glandular epithelium was maintained for day 50 pregnant uterine tissue, with every gland responding and no evidence of hybridization to cells of any other region (data not shown). In near-term uterine tissue (day 140 of pregnancy), strong hybridization was observed in the greatly expanded uterine glands (Fig. 2I). Diffuse hybridization to cells of the myometrium was also observed (data not shown). In situ hybridization for uterine tissue collected at days 10 and 16 of the oestrous cycle and days 9, 17, 20, 40, 50 and 140 of pregnancy yielded no response when a sense ovine GRP riboprobe was used (data for day 40 pregnancy is shown in Fig. $2 \mathrm{H}$ ).

\section{Cellular distribution of GRP immunoreactivity}

Immunohistochemical techniques were used for the cellular localization of GRP peptide in sheep uterus obtained during the oestrous cycle and pregnancy. No peptide could be detected at day 10 of the oestrous cycle (Fig. 2B) in agreement with the lack of GRP mRNA (Figs $1 a$ and 2A). At day 16 of the oestrous cycle, the apical cytoplasm of uterine gland cells stained for GRP immunoreactivity (Fig. 2D). At day 20 of pregnancy, the cytoplasm of uterine gland cells and the area immediately surrounding the glands showed moderately strong staining (Fig. 2F). In near-term uterus (day 140), intense immunohistochemical localization of GRP was observed in the apical cytoplasm of gland cells with immunoreactive material also apparent in the glandular lumen and the stromal tissue surrounding the glands (Fig. 2J). The immunohistochemistry generally reflected the changes seen with in situ hybridization except that no GRP mRNA was detected in stromal tissue.

\section{GRP immunoreactivity in endometrial tissue during the oestrous cycle}

GRP immunoreactivity was low (around $1.2 \mathrm{pmol} / \mathrm{g}$ ) in extracts of endometrium obtained from ewes at days 4, 10, 12 and 14 of the oestrous cycle (Table 1). A significant increase (4-fold; 5.4 pmol/g) was observed at day 16.

GRP immunoreactivity in plasma obtained during the oestrous cycle and early pregnancy

No GRP immunoreactivity could be detected in plasma derived from the peripheral circulation and obtained from sheep at days $4,10,12,14$ and 16 of the oestrous cycle or pregnancy.

\section{Chromatography}

Endometrial tissue was taken from sheep at the mid-luteal phase of the oestrous cycle and 30 and $48 \mathrm{~h}$ after injection of a prostaglandin analogue (equivalent to luteal regression and oestrus respectively), and the molecular forms of GRP immunoreactivity were partially characterized by gel filtration chromatography (Figs 3A, B and C respectively). 

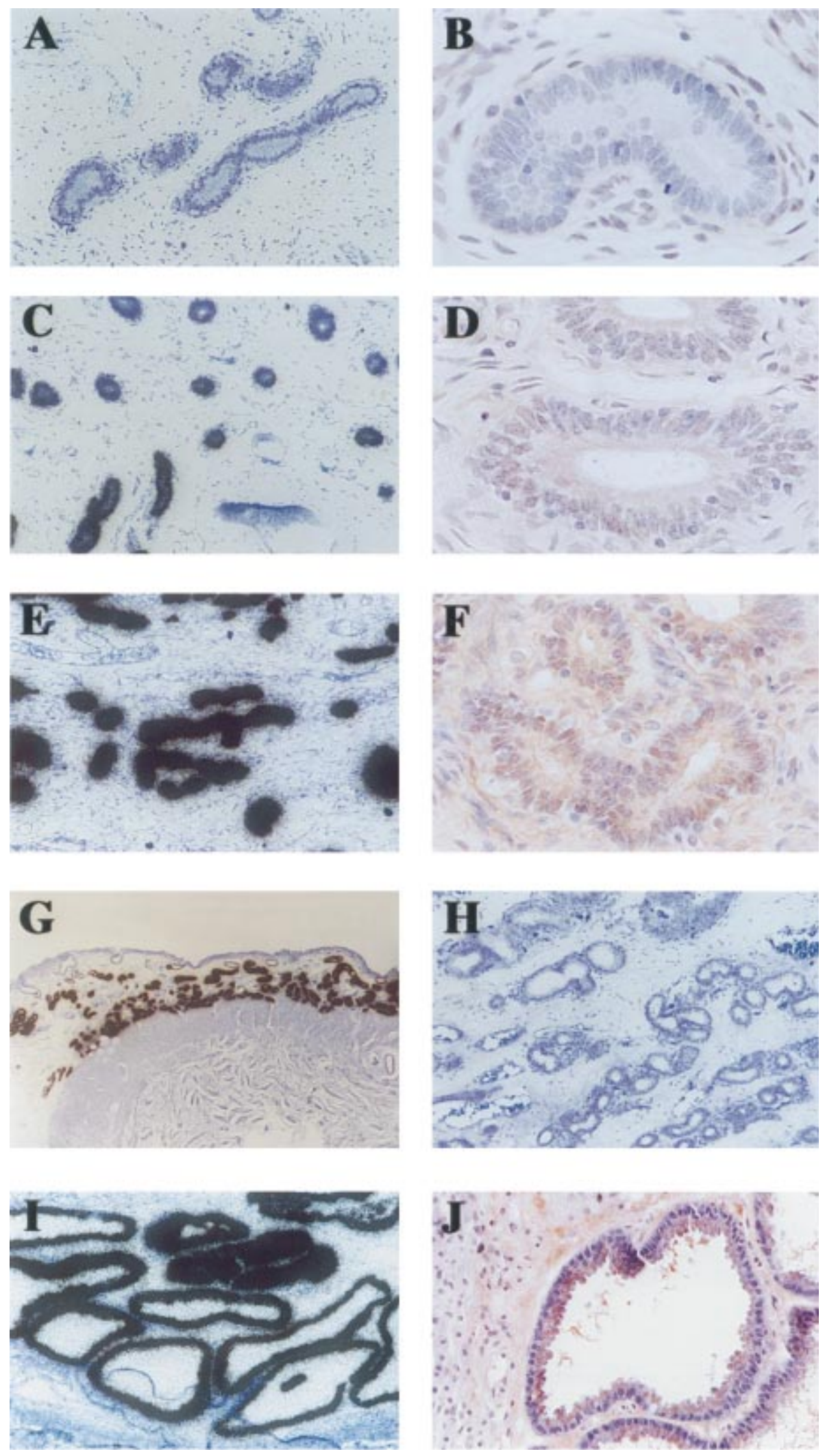
Table 1 GRP immunoreactivity in ovine endometrial tissue isolated on different days of the oestrous cycle. Results are mean \pm S.E.M. ( $n$ in parentheses)

\begin{tabular}{ll} 
& GRP $(\mathrm{pmol} / \mathrm{g})$ \\
\cline { 2 - 2 } $\begin{array}{l}\text { Day of oestrous cycle } \\
4\end{array}$ & $1 \cdot 6 \pm 0 \cdot 4(4)$ \\
10 & $1 \cdot 2 \pm 0 \cdot 2(4)$ \\
12 & $1 \cdot 4 \pm 0 \cdot 2(4)$ \\
14 & $1 \cdot 0 \pm 0 \cdot 2(4)$ \\
16 & $5 \cdot 4 \pm 0 \cdot 6(3)$ \\
\hline
\end{tabular}

The extract from the mid-luteal phase endometrium displayed two molecular forms in approximately equimolar concentrations (Fig. 3A). These two forms were co-eluted with GRP(1-27) and GRP(18-27). The molecular profiles from tissue taken later in the oestrous cycle (Fig. 3B and $\mathrm{C}$ ) showed three molecular mass forms; two of these were co-eluted with GRP(1-27) and GRP(18-27) and the third and predominant form was eluted before (and partly obscured by) GRP(1-27). This higher molecular mass peptide corresponds in elution position to the pregnancy-associated GRP-like peptide, which we have previously described in the gravid ovine endometrium (Giraud et al. 1996) and shown to be larger than human transforming growth factor- $\alpha(5 \cdot 6 \mathrm{kDa})$.

\section{Discussion}

In this study we have shown that a peptide similar to, but larger than, GRP is temporally expressed in the ovine uterus during the oestrous cycle and that GRP mRNA is localized to the glandular epithelial cells during luteolysis, oestrus and pregnancy.

Northern blot analysis, in situ hybridization, RIA and immunohistochemistry revealed that expression of the GRP gene in the ovine uterus varied markedly during the oestrous cycle suggesting a regulated phenomenon. Previous data from our laboratory, and results from this study have suggested that the synthesis of uterine GRP is associated with the presence of a conceptus in the uterus, and is further enhanced after implantation (Giraud et al. 1994). Nevertheless, the present observations of substantial GRP expression in endometrium during the luteal regression phase of the normal oestrous cycle shows that GRP induction is a cyclic phenomenon which is initiated before

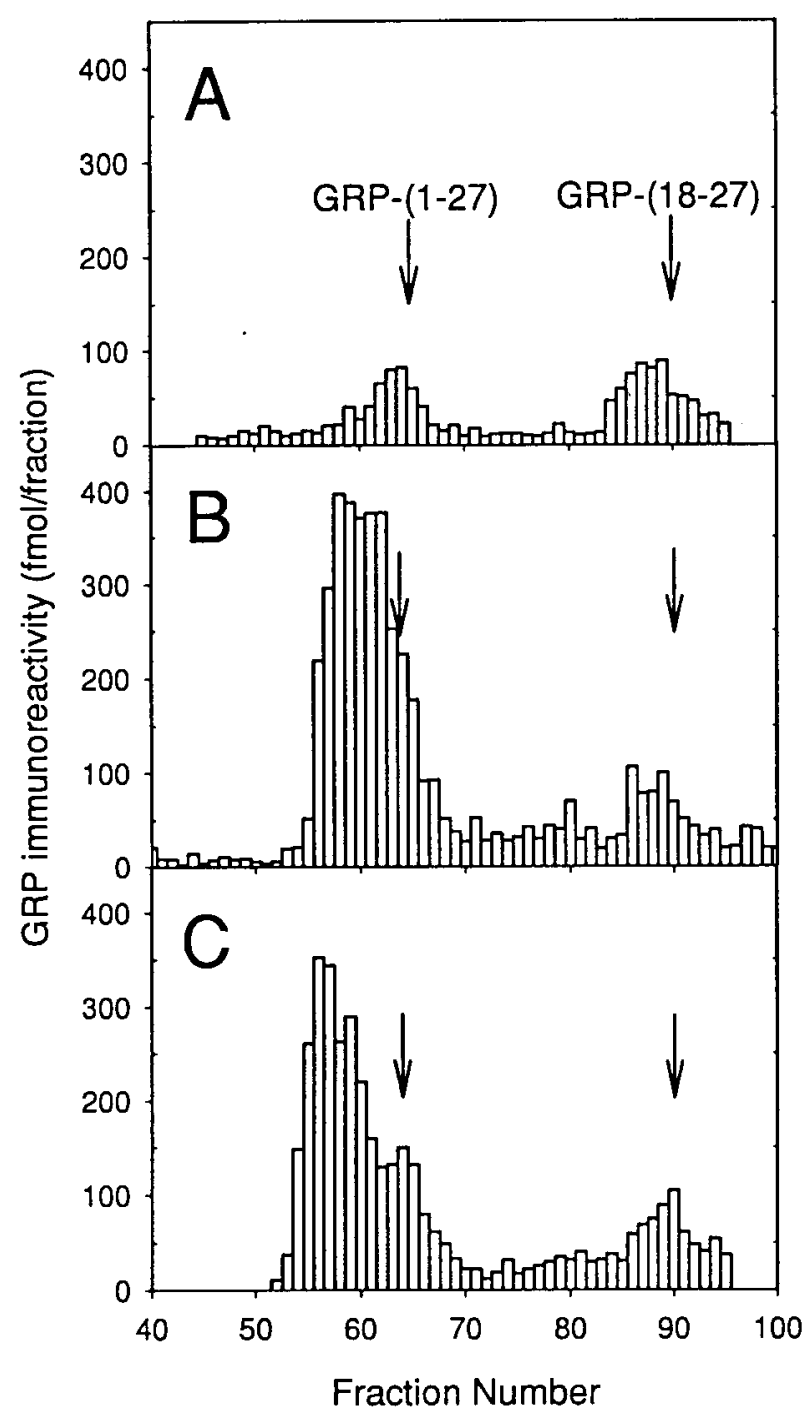

Figure 3 Gel filtration chromatography (Sephadex G-50) of extracts from $11 \mathrm{~g}$ of endometrial tissue isolated from non-pregnant sheep in (A) mid-luteal phase, (B) luteal regression and $(C)$ oestrus. The elution positions of synthetic ovine GRP(1-27) and GRP(18-27) standards are indicated.

conception, and implies that GRP may participate in the cellular changes that occur in the uterus in preparation for pregnancy.

Figure 2 Cell-specific localization of GRP mRNA or peptide in uteri obtained from sheep in the oestrous cycle or pregnancy using in situ hybridization ( $A, C, E$ G, H, I) or immunohistochemistry $(B, D, F, J)$ respectively. The black colour in panels $A, C, E, G, H$ and I indicates hybridization of the GRP antisense riboprobe, and the brown colour in panels $B, D, F$ and J indicates the presence of immunoreactivity. (A) GRP mRNA (magnification $\times 110$ ) and (B) GRP peptide (magnification $\times 500$ ) at day 10 of the oestrous cycle; (C) GRP mRNA $($ magnification $\times 75)$ and $(\mathrm{D})$ GRP peptide (magnification $\times 480)$ at day 16 of the oestrous cycle; (E) GRP mRNA (magnification $\times 160)$ and (F) GRP peptide (magnification $\times 500$ ) at day 20 of pregnancy; in situ hybridization using GRP anti-sense riboprobe (G) (magnification $\times 16)$ and GRP sense probe $(\mathrm{H})$ (magnification $\times 85$ ) at day 40 of pregnancy; (I) GRP mRNA (magnification $\times 90)$ and $(\mathrm{J})$ GRP peptide $($ magnification $\times 220$ ) at day 140 of pregnancy. 
A comparison of the changes in GRP mRNA during the oestrous cycle and pregnancy suggests that regulation of GRP gene expression may be related to ovarian steroid release. GRP mRNA and peptide levels are maximal at day 16 of the oestrous cycle when progesterone is low. However, both GRP mRNA and peptide are elevated at day 20 of pregnancy when progesterone is high. This observation of conflicting relationships between progesterone and GRP suggests that, if progesterone does have a role in regulating GRP gene expression, it can be overcome or modulated by other, probably local, factors. Synthesis of GRP at day 16 of the oestrous cycle correlates with the pre-oestrus surge of oestrogen and also with the concentrations of oestrogen receptors in the superficial and deep glands of the sheep endometrium (Cherny et al. 1991, Wathes \& Hamon 1993). This could suggest that GRP is directly under the influence of oestrogen and acts as a mediator of the actions of oestrogen (i.e. as an oestromedin) on the uterus similar to growth factors such as epidermal growth factor and insulin-like growth factor (Brigstock 1991).

The site of GRP mRNA synthesis in uterine tissue during the luteal regression phase of the oestrous cycle was found to be the epithelial cells of the glands closest to the uterine lumen. However, GRP immunoreactivity was not confined to these cells but also found in the surrounding stromal tissue. This is consistent with rapid secretion of GRP peptide from glandular epithelial cells into the surrounding tissue and ultimately the uterine lumen and circulation and may explain why the increase in GRP peptide (5-fold) between days 14 and 16 of the oestrous cycle was not as marked as the increase observed for GRP mRNA (24-fold). Alternatively the differential between increases in GRP immunoreactivity and mRNA could reflect increased lability of the peptide or less-than-full cross-reactivity of our C-terminally directed antiserum with the endometrially derived GRP. GRP immunoreactivity in the stroma could represent intact peptide or products produced by the action of neutral endopeptidase, which is known to degrade bombesin and is present in the ovine endometrium (Riley et al. 1995). This remains to be determined.

In the ovine uterus, two types of cell were found to synthesize GRP mRNA: glandular epithelium during luteolysis and pregnancy and myometrial cells at the end of pregnancy. An important function of the glandular epithelial cells is production and secretion of the factors that comprise the histotroph such as glycogen, uterine milk proteins and growth factors. In many species, accessory placental structures known as areolae or chorionic vesicles develop opposite the uterine glands and are active in absorption of glandular secretions (King 1993). We propose that a peptide related to, but larger than, GRP be added to the list of components of uterine glandular secretions. The particular functions of this peptide remain to be determined, but, in view of its localization and temporal synthesis, it is likely to have a function in nutrition and/or growth within the ovine utero-foetal axis. The continuous expression from early in gestation until term suggests another possible role in maintenance of the corpus luteum. GRP mRNA detected in myometrium at late gestation could signify a role for GRP in uterine contractions and possibly parturition. Nerve fibres containing GRP immunoreactivity have been observed in the myometrium of rat, guinea pig and pig (Happola \& Lakomy 1989), and GRP and bombesin have been shown to stimulate concentration-dependent contraction of smooth muscle in isolated rat uterus (Stjernquist et al. 1986) mediated via a signal-transduction mechanism coupling a G-coupled seven-transmembrane domain receptor to phospholipase C activation (Amiot et al. 1993).

No GRP immunoreactivity could be detected in peripheral plasma obtained from sheep during the oestrous cycle or early pregnancy in contrast with plasma obtained from mid- and late-term sheep (Giraud et al. 1993) when GRP immunoreactivity is readily detected. This does not mean, however, that GRP is not secreted by the glandular epithelial cells. In a previous study (Giraud et al. 1996), we detected GRP immunoreactivity in uterine flushings during early pregnancy, suggesting that endometrial epithelial GRP is secreted apically. However, as the mass of the endometrium during the oestrous cycle and early pregnancy is relatively small compared with the mid-late-term pregnant uterus, the total amount of GRP reaching the circulation would probably be too low to allow detection.

A novel GRP was identified in the ovine endometrium during luteal regression and oestrus. Gel filtration chromatography suggests that this GRP peptide is larger than GRP(1-27) and GRP(18-27) and similar to the larger GRP previously described in the late-term pregnant uterus (Giraud et al. 1996). Larger forms of GRP mRNA were observed at day 16 of the oestrous cycle and days 14 and 20 of pregnancy. These are similar to the $1.9 \mathrm{~kb}$ and $4.3 \mathrm{~kb}$ transcripts that we observed in RNA prepared from late-term ovine endometrium (Shulkes et al. 1996) and others observed in RNA prepared from pulmonary carcinoid tumour, 18- and 22-week human foetal lung and forebrain (Spindel et al. 1987) and human small cell lung carcinoma cell lines (Sausville et al. 1986) and probably represent GRP mRNA precursors. The larger GRP peptide is unlikely to result from a different transcript arising from an alternative first exon, alternative splicing sites or a second GRP gene since two GRP cDNA clones prepared from pregnant sheep endometrium cDNA library in another laboratory (Fraser et al. 1994) and five GRP cDNA clones prepared in our laboratory (S C Whitley, unpublished observation) are all identical. Predicted translation of the GRP cDNA structure suggests a preproprotein that, if processed similarly to the human and rat preproGRP (Reeve et al. 1988), would yield a signal peptide, GRP(1-27), with an amidated C-terminus (and therefore recognized by the antibody used in our RIA) and 
a C-terminal extension peptide. Further processing of the 27-amino acid peptide would yield a decapeptide identical with human GRP(18-27). The larger than expected GRP observed in the ovine endometrium during luteolysis and late pregnancy may suggest an as yet undescribed processing pathway for preproGRP.

Four subtypes of receptor with affinity for GRP have been identified (Nagalla et al. 1995): GRP-R with greatest affinity for GRP; NMB-R with low affinity for GRP and high affinity for the related peptide neuromedin B; BB4 with greatest affinity for $\left[\mathrm{Phe}^{13}\right]$-bombesin; and BRS-3 with moderate affinity for GRP and as yet no identified ligand. Bombesin receptor subtype 3 (BRS-3) mRNA has been detected using reverse transcription PCR in the pregnant myometrium of guinea pigs (Gorbulev et al. 1992) and women (Fathi et al. 1993, Gorbulev et al. 1994) but not in the non-pregnant myometrium of these species. Our own studies found BRS-3 mRNA to be expressed in the pregnant endometrium, myometrium, amnion, chorion and placenta isolated from three women at term delivery by caesarean section (Whitley et al. 1996). Thus BRS-3 could be the receptor that mediates the actions of the larger form of GRP in the ovine uterus. This possibility is made particularly attractive by the fact that the natural ligand for this receptor has not yet been discovered. Alternatively other GRP receptors may exist. At present, nothing is known of the expression of these receptors in the sheep uterus.

The original discovery of a larger-than-expected GRP in the pregnant sheep uterus (Giraud et al. 1996) was the impetus for the suggestion of a novel role for this misleadingly named peptide. The present study shows that GRP expression in the ovine uterus varies during the oestrous cycle and pregnancy, suggesting temporally dependent regulation at different sites. Cellular localization as deduced by in situ hybridization and immunohistochemistry indicates that GRP is a major transcription and translation product of the epithelial cells of the superficial glands during luteal regression late in the oestrous cycle and also during blastocyst elongation. The additional rise in expression of the GRP gene at the time of blastocyst implantation may indicate a positive feedback mechanism whereby secreted products of the implanting conceptus stimulate further expression of the uterine GRP gene.

In conclusion, our data have shown that a peptide similar to, but larger than, GRP is a major product of the ovine uterus, supporting the hypothesis that a GRPrelated peptide has paracrine and/or autocrine roles in this tissue during the oestrous cycle and pregnancy.

\section{Acknowledgements}

The authors would like to thank Lorraine Parker and Veronica Gazdik from the Department of Medicine, Western Hospital for GRP RIAs and histological assistance respectively and Dr Iain Clarke (Prince Henry's Institute of Medical Research) for providing uterine tissue samples for chromatography. This study was supported by project grants from the National Health and Medical Research Council of Australia and the Austin Hospital Medical Research Foundation.

\section{References}

Amiot F, Leiber D, Marc S \& Harbon S 1993 GRP-preferring bombesin receptors increase generation of inositol phosphates and tension in rat myometrium. American Journal of Physiology 265 C1579-C1587.

Brigstock DR 1991 Growth factors in the uterus: steroidal regulation and biological actions. Baillières Clinical Endocrinology 5 791-808.

Bunnett N 1994 Gastrin-releasing peptide. In Gut Peptides: Biochemistry and Physiology, pp 423-445. Eds JH Walsh \& GJ Dockray. New York: Raven Press.

Cherny RA, Salamonsen LA \& Findlay JK 1991 Immunocytochemical localization of oestrogen receptors in the endometrium of the ewe. Reproduction, Fertility and Development 3 321-331.

Fathi Z, Corjay MH, Shapira H, Wada E, Benya R, Jensen R, Viallet J, Sausville EA \& Battey JF 1993 BRS-3: a novel bombesin receptor selectively expressed in testis and lung carcinoma cells. Journal of Biological Chemistry 268 5979-5984.

Fraser M, Carter AM, Challis JRG \& McDonald TJ 1992 Gastrin releasing peptide immunoreactivity is present in ovine amniotic fluid and fetal and maternal circulations. Endocrinology 131 2033-2035.

Fraser M, McDonald TJ, Spindel ER, Fahy M, Hill D \& Challis JRG 1994 Gastrin-releasing peptide is produced in the pregnant ovine uterus. Endocrinology 135 2440-2445.

Giraud A, Parker L, Taupin D, Hardy K \& Shulkes A 1993 Mammalian bombesin as a hormone in ovine pregnancy: ontogeny, origin, and molecular forms. American Journal of Physiology 265 E866-E873.

Giraud A, Salamonsen, L, Whitley J \& Shulkes A 1994 A peptide related to gastrin releasing peptide is synthesized and secreted by the ovine endometrium in early pregnancy. Endocrinology $\mathbf{1 3 5}$ 2806-2809.

Giraud A, Whitley J, Shulkes A \& Parker L 1996 The pregnant ovine endometrium constitutively expresses and secretes a highly stable bombesin-like peptide, which shares C-terminal sequence but differs structurally from gastrin-releasing peptide. Biochimica et Biophysica Acta 1296 189-197.

Gorbulev V, Akhundova A, Buchner H \& Fahrenholz F 1992 Molecular cloning of a new bombesin receptor subtype expressed in uterus during pregnancy. European Journal of Biochemistry 208 405-410.

Gorbulev V, Akhundova A, Grzeschik KH \& Fahrenholz F 1994 Organization and chromosomal localization of the gene for the human bombesin receptor subtype expressed in pregnant uterus. FEBS Letters 340 260-264.

Happola O \& Lakomy M 1989 Immunohistochemical localization of calcitonin gene-related peptide and bombesin/gastrin-releasing peptide in nerve fibers of the rat, guinea pig and pig female genital organs. Histochemistry 92 211-218.

King BF 1993 Development and structure of the placenta and fetal membranes of nonhuman primates. Journal of Experimental Zoology 266 528-540.

Lawson RAS, Parr RA \& Cahill LP 1983 Evidence for maternal control of blastocyst growth after asynchronous transfer of embryos to the uterus of the ewe. Journal of Reproduction and Fertility $\mathbf{6 1}$ 477-483.

Nagalla SR, Barry BJ, Creswick KC, Eden P, Taylor JT \& Spindel ER 1995 Cloning of a receptor for amphibian $\left[\mathrm{Phe}^{13}\right]$ bombesin 
distinct from the receptor for gastrin-releasing peptide: identification of a fourth bombesin receptor subtype (BB4). Proceedings of the National Academy of Sciences of the USA 92 6205-6209.

Reeve SR Jr, Cuttitta F, Vigna SR, Shively JE \& Walsh JH 1988 Processing of mammalian preprogastrin-releasing peptide. Annals of the New York Academy of Sciences 547 21-29.

Riley SC, Wong E, Findlay JK \& Salamonsen LA 1995 Localization of neutral endopeptidase in the ovine uterus and conceptus during the oestrous cycle and early pregnancy. Reproduction, Fertility and Development 7 27-33.

Rowson LE \& Moor RM 1966 Development of the sheep conceptus during the first fourteen days. Journal of Anatomy 100 777-785.

Salamonsen LA, Doughton BW \& Findlay JK 1986 The effects of the preimplantation blastocyst in vivo and in vitro on protein synthesis and secretion by cultured epithelial cells from sheep endometrium. Endocrinology 119 622-628.

Sausville EA, Lebacq-Verheyden AM, Spindel ER, Cuttitta F, Gazdar AF \& Battey JF 1986 Expression of the gastrin-releasing peptide gene in human small cell lung cancer. Evidence for alternative processing results in three distinct mRNAs. Journal of Biological Chemistry $2612451-2457$.

Shulkes A, Whitley J, Hardy K \& Giraud A 1996 Foetal metabolism, placental transfer and origin of gastrin releasing peptide in the sheep. Clinical and Experimental Pharmacology and Physiology 23 861-865.

Spindel ER, Zilberberg, MD \& Chin WW 1987 Analysis of the gene and multiple messenger ribonucleic acids (mRNAs) encoding human gastrin-releasing peptide: alternate RNA splicing occurs in neural and endocrine tissue. Molecular Endocrinology 1 224-232.

Stjernquist M, Ekblad E, Owman C \& Sundler F 1986 Neuronal localization and motor effects of gastrin-releasing peptide (GRP) in rat uterus. Regulatory Peptides 13 197-205.
Tsonis CG, Cahill LP, Carson RS \& Findlay JK 1984 Identification at the onset of luteolysis of follicles capable of ovulation in the ewe. Journal of Reproduction and Fertility 70 609-614.

Vogiagis D, Salamonsen LA, Sandeman RM, Squires TJ, Butt AR \& Fry RC 1997 Effect of immunisation against leukaemia inhibitory factor on the establishment of pregnancy in sheep and cattle. Reproduction Nutrition Development 37 459-468.

Wathes DC \& Hamon M 1993 Localization of oestradiol, progesterone and oxytocin receptors in the uterus during the oestrous cycle and early pregnancy of the ewe. Journal of Endocrinology 138 479-492.

Whitley J, Giraud A, Salamonsen L, Grant P \& Shulkes A 1994 Expression of gastrin-releasing peptide during pregnancy. Proceedings of the 37th Annual Meeting of The Endocrine Society of Australia, Abstract 55. Melbourne: Endocrine Society of Australia.

Whitley JC, Giraud AS \& Shulkes A 1996 Expression of gastrinreleasing peptide (GRP) and GRP receptors in the pregnant human uterus at term. Journal of Clinical Endocrinology and Metabolism $\mathbf{8 1}$ 3944-3950

Xiao Q, Han X, Challis JR, Hill DJ, Spindel ER, Prasad CJ, Akagi K \& McDonald TJ 1996a Gastrin-releasing peptide-like immunoreactivity is present in human maternal and fetal placental membranes. Journal of Clinical Endocrinology and Metabolism $\mathbf{8 1}$ 3766-3773.

Xiao Q, Challis JRG, Fraser M, Wlodek ME, Thorburn GD, Cuttita F, Hill DJ, St-Pierre S, Spindel ER \& McDonald TJ 1996 b Locations and molecular forms of gastrin-releasing peptide-like immunoreactive entities in ovine pregnancy. Peptides 17 489-495.

Received 8 July 1997

Accepted 13 November 1997 